\title{
A research on the basic psychological needs of swimmers in Kocaeli province in terms of any variances (İzmit district case)
}

\author{
Hakan Akdeniz ${ }^{1 *}$, Özlem Keskin ${ }^{1}$, Fatma Yeşim Körmükçü ${ }^{1}$ and Burak Varol ${ }^{1}$ \\ ${ }^{1}$ Kocaeli University Sports Sciences Faculty Recreation Department
}

\begin{abstract}
This study was conducted with the aim of investigating the basic psychological requirements of swimmers who perform individual sports in Kocaeli province with respect to certain variables. The sample of the study consisted of 80 swimmers who perform individual sports in Kocaeli province, İzmit district between the years of 2016 - 2017, 32 of whom were male and 42 of whom were female. In collecting data, the Basic Psychological Needs Scale which was developed by [4] was used in order to determine the psychological needs of individuals. Basic Psychological Needs Scale was adapted into Turkish by [9] A personal information form that was developed by the researcher was used. No significant difference was observed when basic psychological need scores were compared according to gender $(\mathrm{P}<0,05)$. In consequence of comparing the results of basic psychological need scale by means of age variable, a significant difference was observed by means of the need for relatedness between the $14-16$ and $20-22$ age groups $(\mathrm{P}<0,05)$. When basic psychological need scores were compared with respect to educational background, a significant difference was found in terms of the need for autonomy, need for competence and need for relatedness while a significant difference was observed by means of all scores $(p<0,05)$. With respect to need for autonomy and need for competence; a significant difference was observed between Secondary Education and High School while the need for relatedness and total scores created a significant difference between Secondary Education and University $(p<0,05)$. As a consequence of the comparison between the results of basic psychological need scale according to family attitudes, a significant difference was only observed by means of the need for competence between the variables $(p<0,05)$. With respect to the sub-dimension of the need for competence, a significant difference was found between democratic family structure and authoritarian family structure $(\mathrm{P}<0,05)$. As a result of a comparison between basic psychological needs considering the educational background of female parents, there was a significant difference between the variants by means of the need for competence and the need for relatedness. With respect to need for competence and relatedness, a significant difference was observed for both, between the educational levels of primary school and high school $(\mathrm{P}<0,05)$.
\end{abstract}

* Corresponding author: hakanakdeniz@gmail.com 


\section{Introduction}

Human has in need of several requirements since the birth till the death. Those needs can be accepted as physiological or psychological necessities. [5] expressed that the human has needs that guide specific inborn attitudes of the human.

Imbalance and inadequacy emerge in individuals whose mental needs are not satisfied. This imbalance and inefficacy stress the person out. The organism activates the homeostasis mechanism to normalize this stress stressful situation.

Another dimension within the scope of meeting the human need is the necessities such as the psychological protection.

The reactions in person become positive when the physical and mental needs of him. [2] pointed out that the person can actualize the personality development, bliss and the wellbeing in case of meeting the requirements. In a similar manner, [7] mentioned that growing, surviving and reaching personal maturity take an important place in satisfying the needs. With reference to [5], the human has necessities such as surviving, love, belonging, power and freedom; satisfying the needs of love and belonging eliminates the problems.

Some of the situations like apathy, boredom, discouragement, lack of sense of humor, alienation, selfishness, grudge, anhedonia, joylessness, uneasiness, hopelessness can develop as somatic complaints in human when the physiological and psychological needs are not satisfied [10].

The importance of the surveys and their necessity to be used can be seen in the light of the investigations. It is argued that psychology needs to be used correctly in the sports concept.

Need is the high impulses such as motive, wish, requirement, desire, hope and desire to achieve. The need is explained as a pressure, driving power or necessity that emerge in the brain by an effect from inside or outside. All the psycho-social needs are called as the basic needs [9]. Psychological needs are the center of interest because of being one of the determinants of the human behaviors. [6] who discussed the needs through a hierarchical approach mentioned that other needs emerge from meeting other physiological needs which are the most powerful ones. These newly emerging needs domineer the organism as well as the human needs to become organized in a relative dominance hierarchy.

Murray defined 20 different needs such adaptation, self-determination, submission, success, fun, kinship, tidiness [3]. Glasser who is a theoretician deals with the needs aligned five basic needs that all the people have. These are; surviving, belonging, power, love, freedom, and fun [13].

With reference to the self-determination theory that discusses the psychological needs, people have three main psychological needs as autonomy, competence, and relatedness that are essential for personal development, integrity and psychological health [4]. Autonomy (self-determination) means dealing with the activities which are decided by the person himself; competence means the desire to affect the circle; sense of competence means the capacity to effectively interact with the environment; relatedness means the sense of belonging, namely, a real loyalty to others [4] These needs result from the combination of personal experiences and the environmental factor [11]. 


\section{Methodology}

\subsection{Research Group}

The population was composed of 80 licensed swimmers whose 37 of them were in 14-16 $(46,3 \%)$ age group; 21 of them were in $17-19(26,3 \%)$ age group; $22(27,5 \%)$ of them were in 20-22 age group. The sample of the study was composed of randomized 80 people whose 42 was female and 38 was males from the swimmers of Y1ldzlar Swimming Club, Kocaeli Swimming Club, Akademi Swimming Club and Çınarlı Swimming Clubs.

\subsection{Data Collection Tools}

Basic Psychological Needs scale that was developed by [4] to determine the psychological needs of people was used to collect the data. Besides, personal information form that was developed by the investigator was utilized. Basic psychological needs scale (BPNS) was adapted into Turkish by [9] this scale is a five points Likert scale that consists of 21 items that change between "Absolutely Right (5) Right (4) A bit right (3) Wrong (2) and absolutely wrong (1). The scale is composed of three sub-scales as the autonomy need, competence need and relationship need. As the points of participants increase, it is accepted that the person feels that need more in comparison with other needs.

\subsection{Data Collection}

The survey was applied to participants from Yıldizlar Swimming club, Akademi Swimming club, Kocaeli Swimming club, Çınarlı Swimming Club, Kocaeli Indoor Pool by face to face meeting. Conducting the surveys took 5 days.

\subsection{Analysis of Data}

SPSS 21 (Statistical Package For Social Sciences) packaged software analyzed the data. First of all, the average, standard deviation, frequency and percentage values relating to the variables with descriptive statistics were found. Unpaired t-test was used for the difference between the two groups in data analysis. ANOVA test was used for the difference between more than two groups; Tukey test specified the group created the difference. Significance level was determined as $0,05(\mathrm{p}<0,05)$.

\section{Findings}

Table 1. Frequency analysis distribution of basic psychological needs of swimmers in Kocaeli district based on the ages

\begin{tabular}{llc}
\hline & $\mathbf{n}$ & $\mathbf{\%}$ \\
\hline $14-16$ & 37 & 46,3 \\
$17-19$ & 21 & 26,3 \\
$20-22$ & 22 & 27,5 \\
Total & 80 & 100,0 \\
\hline
\end{tabular}

$46,3 \%$ of the participants were in the $14-16$ age range; $26,3 \%$ of the participants were in the $17-19$ age range; $27,5 \%$ of the participants were in the $20-22$ age range. 
Table 2. Frequency analysis distribution of basic psychological needs of swimmers in Kocaeli district based on the gender

\begin{tabular}{llc}
\hline & $\mathbf{n}$ & $\mathbf{\%}$ \\
\hline Male & 38 & 47,5 \\
Female & 42 & 52,5 \\
Total & 80 & 100,0 \\
\hline
\end{tabular}

$47,5 \%$ of the participants were males; $52,5 \%$ of the participants were the females.

Table 3. Frequency analysis distribution of basic psychological needs of swimmers in Kocaeli district based on the educational background

\begin{tabular}{llc}
\hline & $\mathbf{n}$ & $\mathbf{\%}$ \\
\hline Secondary education & 30 & 37,5 \\
High school & 27 & 33,8 \\
University & 23 & 28,8 \\
Total & 80 & 100,0 \\
\hline
\end{tabular}

$37,5 \%$ of the participants graduated from the secondary education; $33,8 \%$ of the participants graduated from the high school; $28,8 \%$ of the participants were the bachelors.

Table 4. Comparing the basic psychological needs of swimmers in Kocaeli district based on the gender; Distribution by T-test

\begin{tabular}{llcccccc}
\hline & Gender & $\mathbf{n}$ & $\mathbf{x}$ & $\mathbf{s s}$ & $\mathbf{t}$ & $\mathbf{p}$ & Significance \\
\hline \multirow{2}{*}{ Autonomy need } & Male & 38 & 23,3947 & 2,56314 & \multirow{2}{*}{, 267} & \multirow{2}{*}{, 790} & $\mathrm{P}>0,05$ \\
& Female & 42 & 23,2381 & 2,66696 & & & \\
\multirow{2}{*}{ Competence need } & Male & 38 & 19,9211 & 2,12300 &,- 831 &, 408 & $\mathrm{P}>0,05$ \\
\multirow{2}{*}{ Relationship need } & Female & 42 & 20,3095 & 2,05400 & & & \\
& Male & 38 & 26,7368 & 2,40140 &,- 498 & \multirow{2}{*}{620} & $\mathrm{P}>0,05$ \\
\multirow{2}{*}{ Total } & Female & 42 & 27,0238 & 2,71839 & & & \\
& Male & 38 & 70,0526 & 4,36167 & \multirow{2}{*}{,- 480} &, 633 & $\mathrm{P}>0,05$ \\
\hline
\end{tabular}

There was not found a significant difference between the variables at the end of comparing the basic psychological needs scores of the swimmers who participated in the research $(\mathrm{P}<0,05)$

Table 5. Comparing the basic psychological needs of swimmers in Kocaeli district based on the age; Distribution by one way ANOVA analysis

\begin{tabular}{llllllll}
\hline & & $\underline{\mathrm{n}}$ & $\underline{\mathrm{x}}$ & $\underline{\mathrm{ss}}$ & $\underline{\mathrm{f}}$ & $\underline{\mathrm{p}}$ & Significance \\
\hline \multirow{5}{*}{ Autonomy need } & $14-16$ & 37 & 23,7568 & 2,94774 & & & \\
& $17-19$ & 21 & 23,7143 & 2,43193 & 3,011 &, 055 & $\mathrm{P}>0,05$ \\
& $20-22$ & 22 & 22,1818 & 1,76302 & & & \\
& Total & 80 & 23,3125 & 2,60279 & & & \\
& $14-16$ & 37 & 20,0270 & 1,72380 & & & \\
Competence need & $17-19$ & 21 & 19,6190 & 2,83683 & 1,757 &, 179 & $\mathrm{P}>0,05$ \\
& $20-22$ & 22 & 20,7727 & 1,68839 & & & \\
& Total & 80 & 20,1250 & 2,08293 & & & \\
\multirow{5}{*}{ Relationship need } & $14-16$ & 37 & 27,5676 & 2,69300 & & & $14-16$ yaş $-20-22$ \\
& $17-19$ & 21 & 26,8095 & 2,22753 & 3,432 &, 037 & yaş. \\
& $20-22$ & 22 & 25,8182 & 2,34290 & & & \\
Total & Total & 80 & 26,8875 & 2,56063 & & & \\
& $14-16$ & 37 & 71,3514 & 5,07836 & & & P $>0,05$ \\
& $17-19$ & 21 & 70,1429 & 4,79881 & 2,062 &, 134 & \\
\hline
\end{tabular}


There was an observed difference in a relationship needs dimension at the end of comparing the basic psychological needs based on the age. There was no significance in terms of self-determination need, competence need and total scores. A significant difference was observed between 14-16 and 20-22 age groups in a relationship need dimension $(\mathrm{P}<0,05)$.

Table 6. Comparing the basic psychological needs of swimmers in Kocaeli district based on educational background; Distribution by one way ANOVA analysis

\begin{tabular}{|c|c|c|c|c|c|c|c|}
\hline & & $\mathbf{n}$ & $\mathbf{x}$ & ss & f & $\mathbf{p}$ & Significance \\
\hline \multirow{4}{*}{ Autonomy need } & $\begin{array}{l}\text { Secondary } \\
\text { education }\end{array}$ & 30 & 24,0000 & 3,19482 & \multirow{4}{*}{3,786} & \multirow{4}{*}{,027 } & \multirow{4}{*}{$\begin{array}{c}\text { Secondary } \\
\text { education-High } \\
\text { school }\end{array}$} \\
\hline & High school & 27 & 23,5556 & 2,18972 & & & \\
\hline & University & 23 & 22,1304 & 1,74002 & & & \\
\hline & Total & 80 & 23,3125 & 2,60279 & & & \\
\hline \multirow{4}{*}{$\begin{array}{l}\text { Competence } \\
\text { need }\end{array}$} & Secondary & 30 & 20,2333 & 1,73570 & \multirow{4}{*}{3,489} & \multirow{4}{*}{, 035} & \multirow{4}{*}{$\begin{array}{c}\text { Secondary } \\
\text { education-High } \\
\text { school }\end{array}$} \\
\hline & $\begin{array}{l}\text { education } \\
\text { High school }\end{array}$ & 27 & 19,3704 & 2,49843 & & & \\
\hline & University & 23 & 20,8696 & 1,71370 & & & \\
\hline & Total & 80 & 20,1250 & 2,08293 & & & \\
\hline \multirow{4}{*}{$\begin{array}{l}\text { Relationship } \\
\text { need }\end{array}$} & Secondary & 30 & 27,8333 & 2,81723 & \multirow{4}{*}{4,419} & \multirow{4}{*}{, 015} & \multirow{4}{*}{$\begin{array}{l}\text { Secondary } \\
\text { education- } \\
\text { University }\end{array}$} \\
\hline & $\begin{array}{l}\text { education } \\
\text { High school }\end{array}$ & 27 & 26,7407 & 2,14104 & & & \\
\hline & University & 23 & 25,8261 & 2,28935 & & & \\
\hline & Total & 80 & 26,8875 & 2,56063 & & & \\
\hline \multirow{4}{*}{ Total } & $\begin{array}{l}\text { Secondary } \\
\text { education }\end{array}$ & 30 & 72,0667 & 5,22549 & & & \multirow{4}{*}{$\begin{array}{l}\text { Secondary } \\
\text { education- } \\
\text { University }\end{array}$} \\
\hline & High school & 27 & 69,6667 & 4,53194 & 3,561 & 033 & \\
\hline & University & 23 & 68,8261 & 3,95028 & & & \\
\hline & Total & 80 & 70,3250 & 4,80447 & & & \\
\hline
\end{tabular}

There was found a difference in self-determination need, competence need, relationship dimension and total scores at the end of comparing the basic psychological need scores based on the eduction. A significant difference $(\mathrm{P}<0,05)$ was observed between secondary education and university in self-determination need and competence need dimension.

Table 7. Comparing the basic psychological needs of swimmers in Kocaeli district based on family attributes; Distribution by one way ANOVA analysis

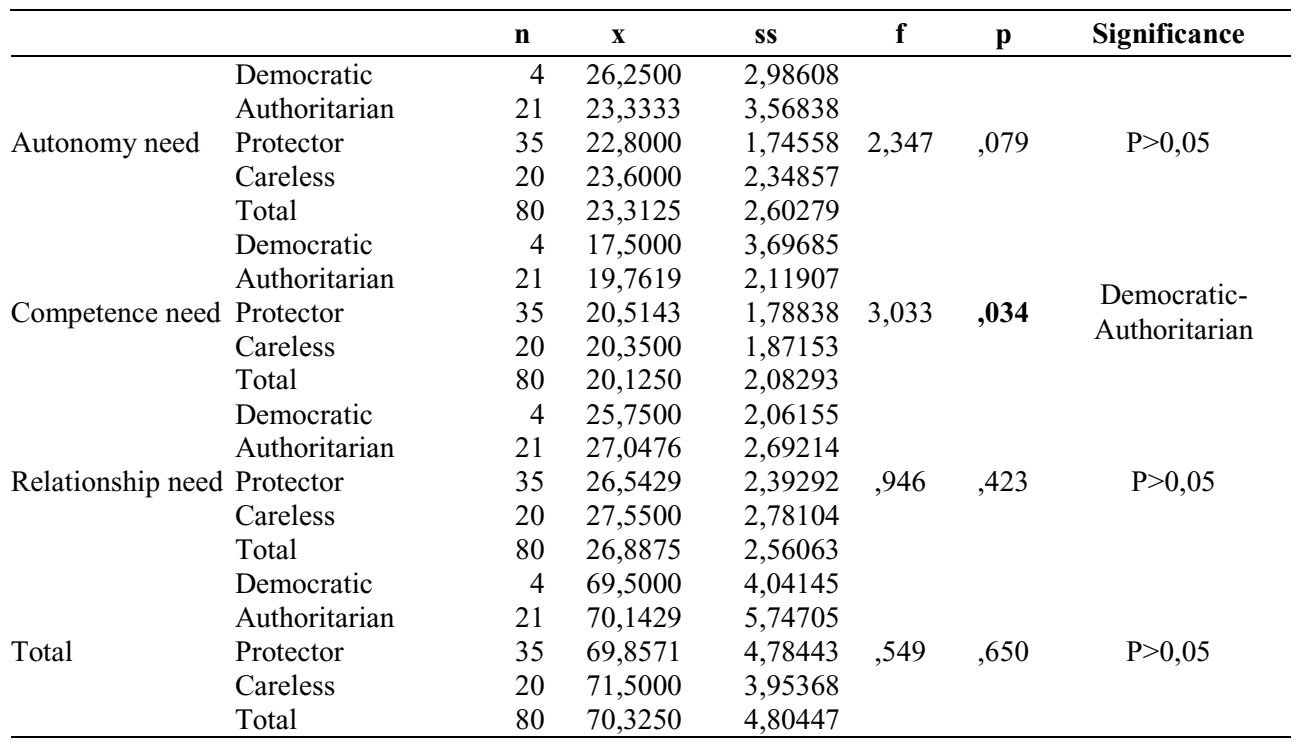


There was observed a difference just in the competence dimension between the variables at the end of comparing the basic psychological need scores based on the family attitudes. There was no significant difference in autonomy need, relationship needs and total scores $(\mathrm{P}<0,05)$. In the competence need dimension, there was observed the difference between democratic family structure and authoritarian family structure $(\mathrm{P}<0,05)$.

\section{Discussions}

This research contains research findings, comparisons, and evaluations of statistical analyses on the data about age, gender, educational background and family attitude variables that may be effective in meeting the basic psychological needs of the students study in secondary education, high school and university in Izmit district of Kocaeli province in Turkey.

There was no significant difference $(\mathrm{P}<0,05)$ between the variables when looking at the comparison of basic psychological needs based on the gender. With reference to this finding, there was no significant difference in comparison of the self-determination, relationship and competence needs of the students based on the gender need.

[8] conducted a study called 'Reviewing the Basic Psychological Needs and Satisfaction Levels of Academicians by Various Variables'. He found a significant difference between self-determination, competence and relationship variables of the academicians based on the gender variable. There is not a parallelism between these two surveys.

There was found a difference between the variables in a relationship need dimension as the result of comparing basic psychological needs based on the age. A significant difference was observed between 14-16 yaş and 20-22 age groups in a relationship need dimension $(\mathrm{P}<0,05)$.

[12] performed a research and found that the self-determination needs significantly varies by the ages of the students. There is seen a parallelism between these two surveys.

A difference was determined between self-determination need, relationship needs, and total scores as the result of comparing the basic psychological need scores based on the educational background. Also, there can be seen a significant difference $(\mathrm{P}<0,05)$ between secondary education and university in relationship need and total scores dimensions. This difference can also be seen between secondary education and high school in selfdetermination need and competence need dimensions.

About this issue, [1] conducted a study and did not found a significant difference between self-determination, competence, and relationship need based on the educational background of volleyball referees. There is not a parallelism in these two surveys.

There was observed a difference just in the competence need between the variables as the result of comparing basic psychological needs based on the family attitudes. A significant difference was observed between democratic family structure and authoritarian family structure in the competence need dimension $(\mathrm{P}<0,05)$.

In other words, the competence needs of the students who have nurturing family attitude are met more in comparison with the same need of the students who have a democratic family attitude.

It is pointed out with reference to these findings that the family attitude is important in decreasing or increasing the competence needs. 


\section{Conclusion}

In other words, the competence needs of the students who have nurturing family attitude are met more in comparison with the same need of the students who have a democratic family attitude.

It is pointed out with reference to these findings that the family attitude is important in decreasing or increasing the competence needs.

\section{References}

1. Arslanoğlu E, Tekin M, Arslanoğlu C, Özmutlu İ. (2010). Voleybol hakemlerinin çeşitli değişkenlere göre kaygı ve temel psikolojik ihtiyaç düzeylerinin incelenmesi (Ankara ili örneği). Uluslararası İnsan Bilimleri Dergisi, 7(2):985-995.

2. Baard, P. P., Deci, E. L. and Ryan, R. M. (2004). Intrinsic need satisfaction: A motivational basis of performance and well-being in two work settings Journal of Applied Social Psychology, 34, 2045-2068.

3. Çivitçi, A. (2012). Üniversite Öğrencilerinde Genel Yaşam Doyum ve Psikolojik İhtiyaçlar Arasındaki İlişkiler. Çukurova Üniversitesi Sosyal Bilimler Enstitüsü Dergisi, 21(2), :321-336.

4. Deci, E. ve Ryan, R. (2000). The "What" And "Why" of Goal Pursuits: Human Needs and The Self- Determination of Behaviour. Psychological Inquiry, 11 (4), 227-269.

5. Glasser, W. (1965). Reality therapy. New York: Harper \& Row Publisher.

6. Maslow, A. H. (1970) Motivation and Personality, Harper \& Row Publishers Second Edition, USA.

7. Ryan, R. M., Sheldon, K. M., Kasser, T. ve Deci, E. L. (1996). All goals are not created equal: An organismic perspective on the nature of goals and their regulation. In P.M. Gollwitzer ve J. A. Bargh (Eds.), The psychology of action: Linking cognition and motivation to behavior (pp. 7-26). New York: Guilford.

8. Türk, S. (2013). "Akademisyenlerin temel psikolojik ihtiyaçlarının ve ihtiyaç doyum düzeylerinin çeşitli değişkenler açısından incelenmesi", Marmara Üniversitesi / Sağlık Bilimleri Enstitüsü / Psikiyatri Hemşireliği Anabilim Dalı, İstanbul.

9. Kesici, Ş., Üre Ö., Bozgeyikli, H., Sünbül, A., M. (2003) Temel Psikolojik İhtiyaçlar Ölçeğinin Geçerlik ve Güvenirliği”. VII. Ulusal PDR Kongresi Bildiri Ö̈zetleri Kitabl, İnönü Ün., Malatya.

10. Özaydın N. (2011). Mesleki Müzik Eğitimi Alan Öğrencilerin Psikolojik İhtiyaçlarının ve Yaşam Doyumlarının İncelenmesi. S.Ü. Eğitim Bilimlerim Enstitüsü, Yüksek Lisans Tezi, Konya.

11. Yavuzer, Y., Gündoğdu, R. (2012). Eğitim Fakültesi Öğrencilerinin Öznel İyi Oluş ve Psikolojik İhtiyaçlarının Demografik Değişkenlere Göre İncelenmesi. Mehmet Akif Ersoy Üniversitesi Eğitim Fakültesi Dergisi, 12(23), 115-131.

12. Yiğit R. (2012). Konya ilinde öğrenim gören yabanc1 uyruklu üniversite Öğrencilerinin temel psikolojik ihtiyaçlarının bir kısım değişkenler bakımından incelenmesi. Selçuk Üniversitesi Sosyal Bilimler Enstitüsü Dergisi, 27, 317-326.

13. Rapport, N., Abbink, J., Canfield, R. L., Denby, D., Keane, W., Neveu, C., ... \& Rapport, N. (2007). An outline for cosmopolitan study: Reclaiming the human through introspection. Current Anthropology, 48(2), 257-283 